\title{
Uterus didelphys and successful pregnancy: case reports
}

\author{
Útero didelfo e gestação bem sucedida: relato de casos \\ Útero didelfo y embarazo exitoso: reporte de casos
}

Hilka Quinelato1, Renata dos Santos Ribeiro Guzman¹, Roberta Faria², Valquiria Quinelato ${ }^{3 *}$.

\begin{abstract}
Objective: To report a clinical cases of uterus didelphys and successful pregnancy. Case details: Case 1: patient with high-risk pregnancy due to Hypothyroidism, overweight and the presence of uterus didelphys. In the past history: anemia, the patient reported menstrual irregularity. The pregnancy went according to the proper procedures, however, a significant increase in weight was observed, as a consequence, gestational arterial hypertension was detected. Cesarean delivery occurred at 37 weeks and three days without complications. Case 2: patient diagnosed with uterus didelphy at 65, history of treatment for becoming pregnant, intense menstrual flow, cramps and two successful pregnancies. However, the patient was not aware of the uterine malformation and there was no information about this fact in the medical record. All patients included in this study provided informed consent. Final consideration: Despite pregnancy being considered the presence of the uterus didelphys, the pregnancies went according to the appropriate procedures considering the guidelines recommended by the Ministry of Health (MS). Therefore, the therapeutic approach applied to clinical cases was successful.
\end{abstract}

Key words: Congenital anomalies, Female infertility, High-risk pregnancy, Mullerian ducts.

\begin{abstract}
RESUMO
Objetivo: Relatar dois casos clínicos de útero didelfo e gestações bem sucedidas. Detalhamento do caso: Caso 1: paciente com gestação de alto risco devido a hipotireoidismo, sobrepeso e presença de útero didelfo. Histórico médico: anemia e relato de irregularidade menstrual. A gestação correu dentro dos tramites adequado, porém, observou-se aumento significativo do peso, como consequência detectou-se hipertensão arterial gestacional. O parto cesariana ocorreu com 37 semanas e três dias sem intercorrências. Caso 2: paciente diagnosticada com útero didelfo aos 65 , histórico de tratamento para engravidar, fluxo menstrual intenso, cólicas e duas gestações bem sucedidas, porém a paciente não tinha conhecimento da presença de malformação uterina, nem havia informações de tal fato no prontuário médico. As participantes de pesquisa incluídas neste estudo assinaram o termo de consentimento livre e esclarecido. Considerações finais: Apesar de a gestação ser considerada presença do útero didelfo, as gravidez correram dentro dos tramites adequados considerando as diretrizes preconizadas pelo Ministério da Saúde (MS). Portanto, a conduta terapêutica aplicada aos casos clínicos foi bem sucedida.
\end{abstract}

Palavras-chave: Anomalias congênitas, Ductos mullerianos, Gravidez de alto risco, Infertilidade feminina.

\section{RESUMEN}

Objetivo: Reportar dos casos clínicos de útero didelfo y embarazos exitosos. Detalle del caso: Caso 1: paciente con embarazo de alto riesgo por hipotiroidimo, sobrepeso y presencia de útero didelfo. Historial médico: anemia e informe de irregularidad menstrual. El embarazo transcurrió de acuerdo con los procedimientos adecuados, sin embargo, se observó un aumento significativo de peso, como consecuencia se detectó hipertensión arterial gestacional. El parto por cesárea ocurrió a las 37 semanas y tres días sin complicaciones. Caso 2: paciente diagnosticada de útero didelfo a los 65 años, antecedente de tratamiento por quedar embarazada, flujo menstrual abundante, cólicos y dos embarazos exitosos. La paciente desconocía que hubiera malformación uterina, tampoco había esa información al respecto en la historia

${ }^{1}$ Facultad Interamericana de Ciências Sociais, Assunção - PY.

2 Prefeitura Municipal de Venda Nova do Imigrante, Venda Nova do Imigrante - ES.

3 Universidade Federal Fluminense (UFF), Niterói - RJ. *E-mail: valquiriaquinelato@yahoo.com.br 
clínica. Los participantes de la investigación incluidos en este estudio firmaron un formulario de consentimiento libre y aclarado. Consideraciones finales: Si bien se considera embarazo a la presencia del útero didelfo, los embarazos se realizaron dentro de los procedimientos adecuados considerando los lineamientos 0 estándares recomendados por el Ministerio de Salud (MS). Por lo tanto, el abordaje terapéutico aplicado a los casos clínicos fue exitoso.

Palabras clave: Anomalías congénitas, Conductos mullerianos, Gravidez de alto riesgo, Infertilidade femenina.

\section{INTRODUCTION}

Uterine malformations or congenital anomalies of the uterus develop during embryonic life, as a result of the failure of resorption or fusion of the Mullerian ducts before the sixth week of gestation the male and female genital organs are indifferent in appearance and form; they are composed of two ducts nearby, paired, they are: paramesonéfrico - Müller; mesonephric - Wolff (FERREIRA AC, et al., 2007; PASSOS IMP e BRITTO $\mathrm{RL}, 2020$ ). The mesonephric duct undergoes degeneration in the absence of the chromosome and determining factor and forms a matrix for the development of the paramesonephric duct (YAMAGUTI EMM, et al., 2009).

The primary components of the female reproductive tract are the Müller's ducts, develop from the mesoderm and form, through their fusion, the tubes, the uterus, the cervix and both proximal and medial thirds of the vagina (PERCOPE FL e AQUINO JHW, 2008; SOUTO MR e CUNHA TM, 2006; PICCININI PS e DOSKI J, 2015; DALL'AGNOL JC, et al., 2016).

During normal Mullerian evolution, there was an ordered embryonic progression and a change in the process of embryogenesis around the sixth week of development, allowing a series of congenital uterine malformations, which result from Müllerian defects and are the most common types of anomalies of the reproductive system (BADALOTTI M, et al., 2005; FERREIRA AC, et al., 2007).

According to the American Fertility Society, uterine abnormalities are classified into: Class I) Hypoplasia/agenesis, class II) unicornuate uterus, class III) didelphys, class IV) bicornus, class V) septate, class VI) arch, class VII) T-shaped uterus resulting from the use of DES (Diethylstilbestrol), and there are still unclassified anomalies (hybrid forms, non-characteristic uterus and cervical and vaginal malformations) (AMERICAN FERTILITY SOCIETY,1988; LUDWIN A e LUDWIN I, 2015). The stage of embryogenesis involved is directly related to the degree of involvement of these organs (SOUTO MR e CUNHA TM, 2006).

The uterus didelphys is a congenital uterine malformation, marked by the complete failure of the lateral fusion of the Müller ducts with the continuous development of the channels, individually, resulting in the presence of two uteri, each uterus receives a tube (two necks, two bodies and may or may not be two vaginas) that is, the woman contains two distinct uteri, separated by a partial vaginal septum or complete, long, reaching the cervix, the final part of the uterus and presenting with renal agenesis (FERREIRA AC, et al., 2007; SOUTO MR e CUNHA TM, 2006; LUDWIN A e LUDWIN I, 2015; ACIÉN P e ACIÉN M, 2016).

Such anomaly is perfectly compatible with fertility and normal menstrual cycles, but sometimes it can cause important clinical problems (FERREIRA AC, et al., 2007). There is a high number of recurrent abortions and reconstructive surgical treatment does not have a satisfactory result. The characteristic that distinguishes the uterus didelphys from bicorneal in the diagnosis is that there is no communication between the uterine cavities (BEGUERÍA R, et al., 2009).

Changes in the uterus do not always indicate that the woman will not be able to have children, many have uterine malformations and are able to conceive normally. In these situations, pregnancy is considered to be at risk, and therefore it is necessary to make an early diagnosis so that adequate follow-up is carried out. Pregnancy by part of the septate uterus, bicornuate or didelphys may be accompanied by bleeding from the non-pregnant part of the uterus, rarely does the pregnancy occur in one half of the uterus after the other half is already pregnant, which is called superfetation (FERREIRA AC, et al., 2007).

With a diagnosis of uterus didelphys, the pregnant woman needs special attention during the entire pregnancy process, due to the increased risk of spontaneous abortion and / or premature birth, which is 
necessary to perform a cesarean section most of the time. In general, it is possible to say that anatomical abnormalities of the uterus do not prevent pregnancy but make it more difficult to remain with a fetus for up to nine months (CASTRO DM, et al., 2013). Even though its etiology is not yet fully known, it is already possible to establish the correlation between possible responsible people and their way of acting with genetic, chromosomal, environmental, family and teratogenic agents. In short, these anomalies have a multifactorial etiology (XU Z, at al., 2017; PASSOS IMP e BRITTO RL, 2020).

In this context, there is a need for a better understanding of the uterine malformation process, consequently, a more effective determination of the diagnosis and gestational follow-up, in order to lead the pregnancy until an appropriate time. Therefore, the aim of this study was to report a clinical case of uterus didelphys and successful pregnancy.

\section{CASE DETAILS}

\section{Case 1}

\section{Pre-pregnancy}

Patient, 30 years old, female, caucasian, married, maid. At the age of 26, she visited the Basic Health Unit in February/2012, during anamnesis she reported menstrual irregularity and used the Nocyclin contraceptive method (EMS S/A, São Bernardo do Campo/SP). On this date, a complete blood test was requested, after 15 days, the patient returned to the medical consultation and requested obstetric ultrasound $(\mathrm{OU})$ and urine analysis (EAS). In April/2012 she returned to show the results of blood tests and OU, a doctor prescribed injectable Noripurum (Bipso $\mathrm{GmbH}$, Singen, Germany) due to anemia and contraceptive switch to cycle 21. Two months later she repeated a complete blood count.

In December/2012, she sought the unit again, reported menstrual bleeding 40 days before, and the contraceptive was changed to Microvlar (Schering do Brasil, Química e Farmacêutica Ltda. São Paulo - SP) after bleeding ceased, laboratory tests were requested and prescription of Transamim (Hypofarma Instituto de Hypodermia e Farmácia LTDA, Ribeirão das Neves/MG-Brazil) 1 tablet 8-8H. May/2013 she presented the results of the exams, Ferrous Sulfate was prescribed, $40 \mathrm{mg}, 1$ tablet before meals for 6 months. The Microvlar (Schering do Brasil, Química e Farmacêutica Ltda) contraceptive was replaced. by Selene (Eurofarma, Ribeirão Preto - SP) 3 packs.

She returned in June/2013 to order and show tests including thyroid exam (TSH) and free thyroxine (T4) and thyroid ultrasound. In October 2013 she returned with results of laboratory tests and OU. Combiron (Ache, Guarulhos - SP) was prescribed 1 tablet daily for 90 days and asked to repeat platelets and medical plans to assess the possibility of referral to a hematologist. Apr/2016, thyroid medications were prescribed: Levotiroxina 25mg (Merck do Brasil, Jacarepaguá - RJ).

For several days she returned to ask for exams and show results. In April/2017, she did the first preventive. There was no report of a history of uterus didelphys in the medical record (result of the preventive within normal limits). Follow-up with laboratory tests continued.

\section{Gestation}

In Sep/2017 BHCG was requested; in Oct/2017 the patient returned to the unit with a positive BHCG result; patient referred for prenatal care. According to the date of the last menstruation (LMP) (15-08-2017), the gestational age (GA) was 8 weeks, and the probable date of delivery (DPP) would be 20-05-2018. At that moment, the patient was using levothyroxine $25 \mathrm{mg}$ (Merck do Brasil, Jacarepaguá - RJ) for hypothyroidism.

Laboratory tests and $\mathrm{OU}$ were requested, prescription of ferrous sulfate and folic acid (continuous use until the end of pregnancy). The patient was referred to a nutritionist and an obstetrician gynecologist for monitoring of high gestational risk (Obesity, Hypothyroidism). In the second prenatal consultation, the participant showed results of laboratory tests without changes and showed, at that time, OU performed in 2012. Cervix anatomical changes were observed: bicornuate uterus and biculus, as shown by the first OU (Figure 1) (Table 1) (Table 2). 
Figure 1 - First obstetric ultrasound demonstrating the presence of a uterus didelphys with pregnancy in the left uterus and the presence of a live fetus. Image obtained from OU.
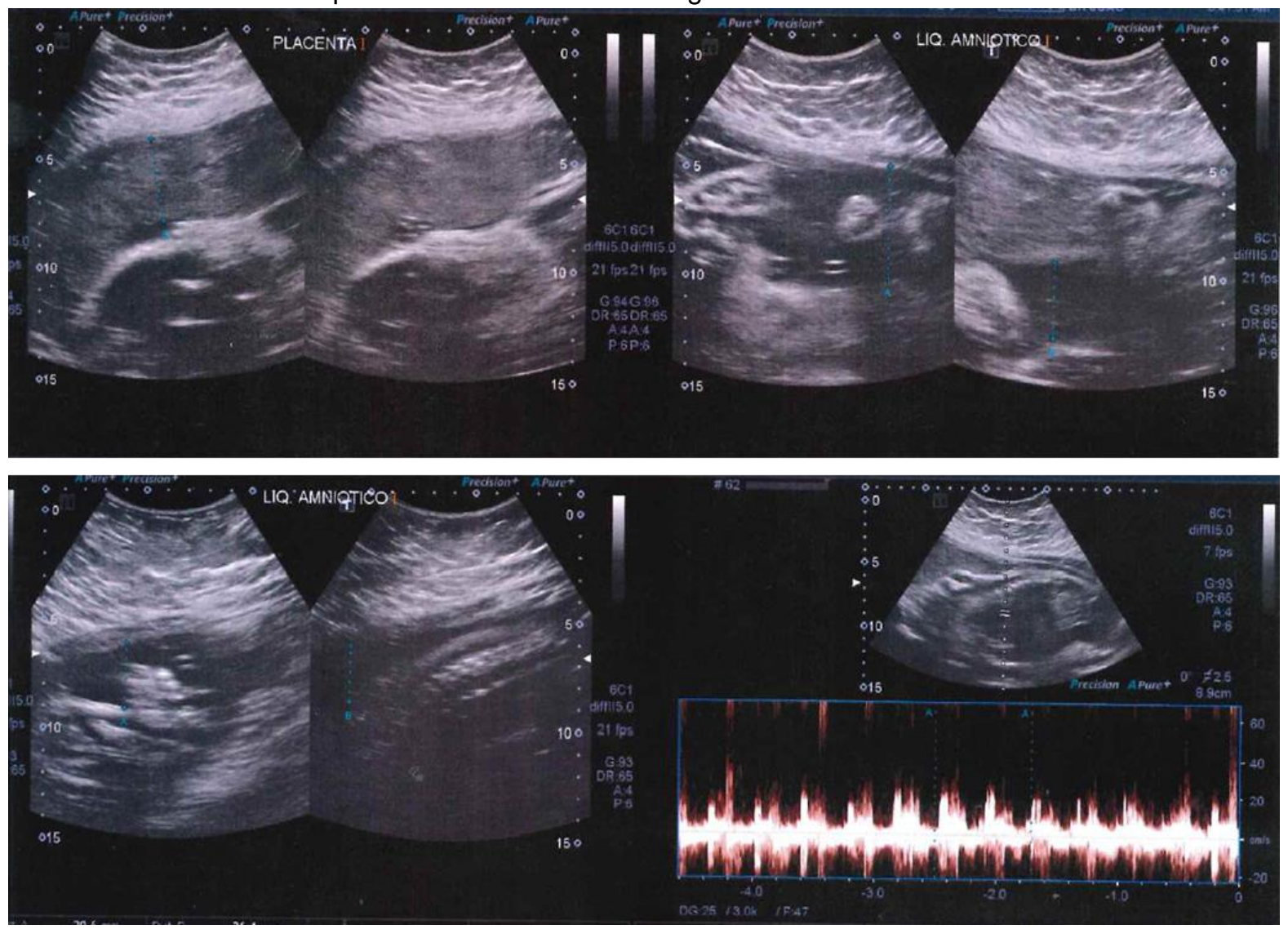

Source: Quinelato H, et al., 2021.

Third prenatal consultation, she reported having suffered a fall from her own height at her residence, without clinical complaint, and requested another OU. Fourth prenatal consultation, showed result of the second OU as shown in Table 1, requested new OU, received recommendations about blood pressure. Fifth prenatal consultation showed a third OU as shown in Table 2, blood pressure was assessed (Table 1). Sixth prenatal consultation, constant observations regarding blood pressure. Requested last OU. Seventh prenatal visit, hypertension detected, medication started with Methyldopa $500 \mathrm{mg}$ (EMS S/A. Hortolândia-SP-Brasil) - 1 tablet $12 \mid 12 \mathrm{~h}$. Patient showed the fourth OU (Table 2).

Table 1 - Demonstration of the evolution of obstetric consultations.

\begin{tabular}{cccccccc}
\hline \multirow{2}{*}{ Parameters } & \multicolumn{7}{c}{ Medical appointment } \\
\cline { 2 - 8 } & 1st & 2nd & 3rd & 4th & 5th & 6th & 7th \\
\hline Date & Oct $/ 17$ & Nov/17 & Dec/17 & Jan/18 & Feb/18 & Mar/18 & Apr/18 \\
${ }^{*}$ GA (OU) & $08 \mathrm{w}^{* *}$ & $12 \mathrm{w} 6 \mathrm{~d}^{* * *}$ & $18 \mathrm{w}$ & $21 \mathrm{w}$ & $26 \mathrm{w} 1 \mathrm{~d}$ & $30 \mathrm{w}$ & $35 \mathrm{w}$ \\
Weight & 103.900 & 102.600 & 102.300 & 103.600 & 104.950 & 108.000 & 113.000 \\
Blood Pressure & $120 \times 80$ & $120 \times 80$ & $120 \times 80$ & $130 \times 80$ & $130 \times 80$ & $140 \times 80$ & $140 \times 80$ \\
\hline
\end{tabular}

Professional assistance

General practitioner

Legends: *Gestational age; **weeks; ${ }^{* *}$ days. Reference values obtained from Obstetric ultrasound (OU) and Medical Record.

Source: Quinelato H, et al., 2021. 
Table 2 - Result of Obstetric Ultrasonography (OU).

\begin{tabular}{|c|c|c|c|c|c|}
\hline Date & $\begin{array}{l}\text { Gestational } \\
\text { Age (OU) }\end{array}$ & $\begin{array}{c}\text { Fetal } \\
\text { Weight }\end{array}$ & Placenta & $\begin{array}{c}\text { Amniotic } \\
\text { fluid }\end{array}$ & Note \\
\hline Oct/17 & $\begin{array}{l}11 \text { weeks, } 5 \\
\text { days }\end{array}$ & - & & normal & $\begin{array}{l}\text { Nuchal transluncence: uterus didelphys } \\
\text { with pregnancy on the left, live fetus }\end{array}$ \\
\hline Dec/17 & $\begin{array}{l}19 \text { weeks, } 1 \\
\text { day }\end{array}$ & $266 \mathrm{~g}$ & Previous & normal & $\begin{array}{c}\text { Biometrics compatible with } 19 \text { week, } 1 \\
\text { day. Uterus didelphys with regnancy on } \\
\text { the left }\end{array}$ \\
\hline Jan/18 & $\begin{array}{l}21 \text { weeks, } 2 \\
\text { days }\end{array}$ & $400 \mathrm{~g}$ & Grede I & normal & $\begin{array}{c}\text { Biometrics compatible with } 21 \text { week, } 2 \\
\text { day }\end{array}$ \\
\hline Mar/18 & $\begin{array}{c}32 \text { weeks, } 2 \\
\text { days }\end{array}$ & $1,936 \mathrm{~g}$ & Grade II & normal & $\begin{array}{l}\text { Pelvic presentation, fetal face not } \\
\text { evaluated. }\end{array}$ \\
\hline
\end{tabular}

Legends: Reference values obtained from Obstetric ultrasound and Medical Record.

Source: Quinelato H, et al., 2021.

\section{Delivery}

In the postpartum (puerperal) consultation in May/18, blood pressure $120 \times 80 \mathrm{mmhg}$, weight $102 \mathrm{~kg}$, refers to uneventful delivery. Cesarean delivery in late April 2018 with 37 weeks and three days, newborn with $2.490 \mathrm{~kg}$, height $45 \mathrm{~cm}$, head circumference $33 \mathrm{~cm}$, apgar 8/9. According to the mother's reports, sunbathing was initiated due to jaundice.

\section{Case 2}

Patient 65 years old attended the ESF, in 2019, for regular genicological consultation in which the presence of a uterus didelphys was diagnosed (Figure 2). In the past history, the participant reported that during menstrual periods, blood flow was intense, and cramps confirmed. Menarche occurred at age 14, married at age 25, used oral contraceptives for only two months ( 1 month before and one after marriage), noticed amenorrhea and used medication, chose to become pregnant, failing in the first months, started treatment with a gynecologist, the follow-up lasted for approximately 12 months.

Then she discovered pregnancy, the pregnancy went smoothly, delivery was natural. After 1 year, she discovered another pregnancy, c-section delivery, during delivery performed tubal ligation. The patient reported not being aware of the existence of uterine malformation.

Figure 2 - Picture demonstrating the presence of a uterus didelphys, case 2 .

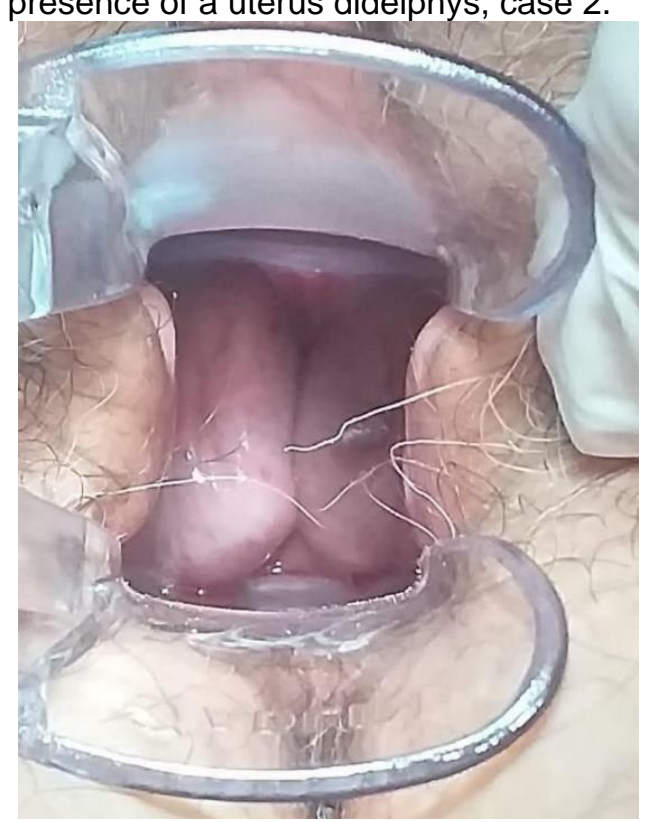

Source: Quinelato H, et al., 2021. 


\section{DISCUSSION}

Uterine malformations are a great challenge for gynecologists, as they are asymptomatic situations in childhood and adolescence, however, the statistics are flawed, and the incidence is not exact. Most of the data are the results of studies of obstetric complications or infertility, and many women are not diagnosed, especially if they are asymptomatic. This study is about two case reports of uterus didelphys and successful pregnancy which diagnosis was made during pregnancy and regular gynecological consultation respectively (TORGAL I e CARVALHO MJ, 2009; FERREIRA AC, et al., 2007; MACHADO D e GOMES RL, 2013; BADALOTTI M, et al., 2005).

The incidence of congenital anomalies varies from $0.1 \%$ to $6,7 \%$ of women, in the general population, but the incidence can reach $16,7 \%$ in women with recurrent abortions (PERCOPE FL e AQUINO JHW, 2008; PICCININI PS e DOSKI J, 2015; DALL'AGNOL JC, et al., 2016; PASSOS I e JESUS RVS, 2017; KNEZ J, et al., 2017; PASSOS IMP e BRITTO RL, 2020). Sometimes they are diagnosed through menstrual changes at puberty or, when the diagnosis is late, it can be made from infertility or obstetric complications (PERCOPE FL e AQUINO JHW, 2008; PICCININI PS e DOSKI J, 2015; DALL'AGNOL JC, et al., 2016; PASSOS I e JESUS RVS, 2017; KNEZ J, et al., 2017; FERREIRA AC, et al., 2007).

Data that corroborate the clinical findings of these case reports, in case 1, the 26-year-old research participant presented as an initial complaint: report of menstrual irregularity. However, the diagnosis of uterus didelphys was confirmed years later with the first obstetric ultrasound, in 2017, confirming the 11-week pregnancy. Although the research participant underwent an ultrasound examination in 2012. This scenario may also have been influenced by the turnover of health professionals working in the Family Health Program (PSF). This rotation, imposed by the system that governs the hiring of these professionals in Brazil (2-year contracts may or may not be extended for another 2 years) (BRASIL, 2020).

Due to this turnover of health professionals, patients find it difficult to continue their treatments, as it is necessary to re-establish trust between professional and patient. In case 2, the late diagnosis of uterus didelphys occurred at 65 years of age, despite the fact that it reported the blood flow was intense, the presence of intense colic and findings. In addition, having undergone treatment to get pregnant for approximately 1 year until successful. These data corroborate with the literature where he stated that the diagnosis usually occurs late (FERREIRA AC, et al., 2007; PERCOPE FL e AQUINO JHW, 2008).

Uterine malformations have an old history in the literature, cases like this study are not justified. Therefore, one of the main classifications of Mullerian anomalies was proposed by Jarcho in 1946, later adapted by Zanetti and based on embryonic development. This classification was later modified by Butram and Gibbons, in 1975/1979. Then the malformations were named in uteri: unicornuate, bicornuate, didelphys and septate. A classification with similarities in clinical characteristics, treatment and prognosis. In 1988 it was modified by the American Fertility Society (SAF) and adopted by the same Society until today (FERREIRA AC, et al., 2007; SOUTO MR e CUNHA TM, 2006; LUDWIN A e LUDWIN I, 2015).

Since the 1980s, ultrasound has become an indispensable procedure for gynecological practice, contributing and modifying concepts and procedures within the specialty, with greater benefit in the uterus noninvasive evaluation. Initially with the two-dimensional modality (2D) through the abdominal route and then through the endovaginal route. Subsequently, the ultrasound was added to three-dimensional (3D) processing. Magnetic resonance imaging is also used in many services (FERREIRA AC, et al., 2007).

Currently, 3D ultrasound is the most specific diagnostic method. However, due to its higher cost and lower availability, 2D ultrasound is the most used. Over the past decade, the role of 3D ultrasound has been extensively researched, discussed and many works has been published about this (FERREIRA AC, et al., 2007). The most frequent signs and symptoms are according to the types of malformations, however, the most common are: cyclic and abdominal pelvic pain, palpable pelvic mass and dysmenorrhea. Amenorrhea, dyspareunia, urinary retention, infertility and obstetric complications are less common. However, these manifestations are more painful, when the vaginal septum merges with the vaginal wall, leading to a complete obstruction; if incomplete, the symptoms may be late or subtle (ACIÉN P e ACIÉN M, 2016; PASSOS I, et al., 2017). 
Congenital uterine malformations can also be associated with recurrent miscarriage, premature birth, anomalous fetal presentations, infertility, complicated pregnancies and breech presentations. In addition, in some women the most frequently associated urinary tract changes are: renal agenesis, duplication of the uterus and/or vagina, renal duplication and horseshoe kidney (ACIÉN P e ACIÉN M, 2016; DALL'AGNOL JC, et al., 2016; PICCININI PS e DOSKI J, 2015).

The treatment of the various Müllerian malformations comprises several methods in the gynecological propaedeutics for evaluation and diagnosis. As an example, we can mention the radiological exams through hysterosalpingography, surgical procedures - laparotomy, laparoscopy and more recently videolaparoscopy and hysteroscopy (FERREIRA AC, et al., 2007; YAMAGUTI EMM, et al., 2009).

As there is still no consensus on the impact of the anomaly on fertility, diagnosis and classification are of paramount importance to enable the therapeutic conduct and prognosis to be adequate (BADALOTTI M, et al., 2005). Within this context, the importance of these case reports demonstrating gestational success in uterus didelphys is emphasized. Although pregnancy is considered a high risk due to the patient's weight and the presence of the uterus didelphys, the pregnancy went according to the appropriate procedures, that is, within the weeks recommended by the Ministry of Health in case 1. However, a significant increase in weight was observed, as a consequence, gestational arterial hypertension was detected. Therefore, the clinical conduct applied to high-risk pregnancies was considered successful.

\section{REFERENCES}

1. ACIÉN P, ACIÉN M. The presentation and management of complex female genital malformations. Human Reproduction Update, 2015; 0(0):1-22.

2. ACIÉN P, ACIÉN M. Diagnostic imaging and cataloguing of female genital malformations. Insights Imaging, 2016; 7:713-726.

3. AMERICAN FERTILITY SOCIETY. The American Fertility Society classifications of adnexal adhesions, distal tubal occlusion, tubal occlusion secondary to tubal ligation, tubal pregnancies, müllerian anomalies and intrauterine adhesions. Fertility and Sterility, 1988; 49(6):944-955.

4. BADALOTTI M, et al. Utero septado, duplicación del cuello y septo vaginal: informe de una rara. Revista Colombiana de Obstetricia y Ginecologia, 2005; 56:244-248.

5. BEGUERÍA R, et al. Malformaciones Müllerianas: clasificación, diagnóstico y manejo. Ginecología y Obstetricia Clínica, 2009; 10(3):165-169.

6. BRASIL. Processo seletivo simplificado para suprimento de vagas em regime de designação temporária de excepcional interesse público - Edital de abertura № 002/2020.

7. CASTRO DM, et al. Pregnancy after assisted reproductive treatment in Herlyn-Werner-Wunderlich Syndrome. Acta Obstétrica e Ginecológica Portuguesa, 2013; 7(4):312-315.

8. DALL'AGNOL JC, et al. Síndrome de Herlyn Werner Wünderlich: relato de caso. Revista Thêma et Scientia, 2016; 6:232-236.

9. FERREIRA AC, et al. Three-dimensional ultrasound in gynecology: uterinemalformations. Radiologia Brasileira, 2007; 40(2):131-136.

10. KNEZ J, et al. ESHRE/ESGE female genital tract anomalies classification system-the potential impact of discarding arcuate uterus on clinical practice. Human Reproduction, 2018; 33(4):600-606.

11. LUDWIN A, LUDWIN I. Comparison of the ESHRE-ESGEand ASRM classifications of Mullerianduct anomalies in everyday practice. Human Reproduction 2015; 30:569-580.

12. MACHADO D, GOMES RL. Gestações a termo em útero com malformação mülleriana. Revista Médica Ana Costa, 2013; 18:1-23.

13. PASSOS I, et al. Síndrome de Herlyn-Werner-Wunderlich: patología que todo ginecólogo debe reconocer. Adolescência e Saúde, 2017; 14:102-106.

14. PASSOS IMP, BRITTO RL. Diagnosis and treatment of müllerian malformations. Taiwanese Journal of Obstetrics \& Gynecology, 2020; 59:183-188.

15. PERCOPE FL, AQUINO JHW. Syndrome of Herlyn-Werner-Wunderlich: a diagnosis that we need to know. Adolescencia e Saúde, 2008; 5(3):23-26.

16. PICCININI PS, DOSKI J. Herlyn-Werner-Wunderlich syndrome: a case report. Revista Brasileira Ginecologia e Obstetrícia, 2015; 37(4):192-196.

17. SOUTO MR, CUNHA TM. Malformações Uterinas: Revisão Clínica e Imagiológica. Acta Radiológica Portuguesa, 2006; 18(71):89-93.

18. TORGAL I, CARVALHO MJ. Embriologia do Aparelho Genital Feminino. In: Manual de Ginecologia, 2009; 1:109-118.

19. YAMAGUTI EMM, et al. Ultra - Sonografia tridimensional e malformações müllerianas. EURP, 2009; 1(3):157-162.

20. XU Z, at al. Genetic association between PAX2 and mullerian duct anomaliesin Han Chinese females. Journal of Assisted Reproduction and Genetics, 2017; 34:125-129. 